Andrzej Kobus

(Uniwersytet Jana Kochanowskiego w Kielcach

Filia w Piotrkowie Trybunalskim)

\title{
KOŚCIÓŁ KATOLICKI I ŻYCIE RELIGIJNE POLAKÓW W ŻYTOMIERZU W LATACH 1917-1991
}

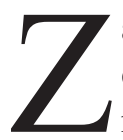

awarcie w 1569 r. unii lubelskiej zaowocowało m.in. faktem, iż dotychczasowe księstwo kijowskie weszło w skład Korony na zasadach odrębnego województwa. Na jego zaś terenie położony był Żytomierz, pełniący od tej pory funkcję siedziby powiatu i starostwa grodowego oraz miejsca, gdzie odbywały się sejmiki powiatowe. Niedługo potem, w 1596 r., król Zygmunt III Waza wyznaczył w Żytomierzu dwa jarmarki mające trwać aż po dwa tygodnie. Dzięki temu posunięciu ożywił się handel w mieście i rosła zasobność jego mieszkańców. Ciężkie czasy spadły na Żytomierz wraz z wybuchem powstania Chmielnickiego. Miasto zostało bowiem wówczas zajęte przez oddziały kozackie, co wiązało się z niezwykłymi zniszczeniami i stratami dla mieszczan żytomierskich. Odbudowa Żytomierza rozpoczęła się dopiero w drugiej połowie XVII w. W tym czasie, tj. po utracie przez Rzeczpospolitą Kijowa, Żytomierz został stolicą województwa kijowskiego.

Kolejne stulecie znamionowały m.in. przybycie do Żytomierza jezuitów (1724 r.), bernardynów (ok. 1761 r.), a w 1783 r. księży misjonarzy ${ }^{1}$. Zresztą rok 1724 był szczególnie ważny dla Żytomierza, ponieważ wtedy przeniesiono tam siedzibę diecezji kijowskiej² ${ }^{2}$ W międzyczasie miasto doświadczyło poważnych strat $\mathrm{w}$ związku z działaniami wojennymi w okresie konfederacji barskiej (1768-1772). Żytomierz, gdzie w pierwszym okresie konfederacji, tj. w 1768 r., toczyły się zacięte walki konfederatów z Rosjanami, spłonął, do czego w ogromnym stopniu „przysłużyła się” drewniana zabudowa miasta. Intensywne walki toczyły się także pod nieodległym Berdyczowem, gdzie konfederaci bronili silnie umocnionego klasztoru.

W 1793 r. Żytomierz (w wyniku drugiego rozbioru Polski) został przyłączony do Rosji, a car Paweł I wyznaczył miasto na siedzibę guberni wołyńskiej. Dodatkowo do 1798 r. wraz z powstaniem arcybiskupstwa mohylewskiego, Żytomierz został

${ }^{1}$ K. Naskręcki, Z zapisków i ze wspomnień Żytomierzanina, oprac. M. Dębowska, Kraków 2011, s. 19.

2 М.Ю. Кистириця, Р.Ю. Кондратюк, Житомир, Житомир 2007, s. 67. 
wyznaczony na stolicę nowej diecezji łucko-żytomierskiej ${ }^{3}$. Pod panowaniem Romanowych Żytomierz kontynuował swój rozwój. Powstało Stowarzyszenie Księgarsko-Wydawnicze ${ }^{4}$, Towarzystwo Dobroczynności, teatr. W Żytomierzu od 1844 r. do 1920 r. rezydował biskup diecezji łucko-żytomierskiej5.

Lata tzw. Wielkiej Wojny, czyli I wojny światowej, przyniosły miastu kolejne zmiany. Żytomierz, a przede wszystkim jego ziemiańskie okolice i tamtejsze katolickie duchowieństwo, doświadczyły w drugiej połowie 1917 r. polityki Centralnej Rady Ukraińskiej zakładającej przejmowanie własności prywatnej i kościelnej ${ }^{6}$. Na tym polu w wielu miejscowościach doszło do pogromów ${ }^{7}$.

Wiosną 1918 r. do Żytomierza dotarły jednostki niemieckie w ramach wielkiej ofensywy pruskiej na Wschodzie. Fakt ten zdecydowanie uspokoił żywioł ukraiński, który był żądny rozliczeń z polskimi elitami ${ }^{8}$.

Z kolei wiosną 1919 r. Żytomierz, podobnie jak Kijów, został zajęty przez bolszewików. Z miasta uciekł biskup Ignacy Dubowski, który udał się do Łucka. Powrócił tylko na krótko, za sprawą polskiej wiosennej ofensywy 1920 r., dzięki której Żytomierz udało się na jakiś czas wyswobodzić spod rządów „,czerwonego caratu". Jednak kiedy wojska polskie wycofały się z centralnej Ukrainy w czerwcu 1920 r., decyzję o ostatecznym wyjeździe podjął i biskup Dubowski.

W powstałym w 1922 r. Związku Socjalistycznych Republik Radzieckich Żytomierz został stolicą jednego z obwodów radzieckiej Ukrainy. ZSRR był państwem o zdecydowanie ateistycznej proweniencji, gdzie na dodatek władza pragnęła wykreować tzw. człowieka radzieckiego, dalekiego zarówno od tożsamości religijnej, jak i narodowej. Pewnym odstępstwem od tej polityki było utworzenie w 1925 r. tzw. marchlewszczyzny, czyli Polskiego Rejonu Narodowego im. J. Marchlewskiego (istniał do 1935 r.).

Tym niemniej Kościół katolicki na terenie Żytomierza trwał. Wikariuszem generalnym diecezji żytomirskiej pod nieobecność ordynariusza bpa Dubowskiego został ks. Teofil Skalski, będący od 1926 r. administratorem apostolskim ${ }^{10}$. W połowie tamtego roku, a dokładnie 2 czerwca, ks. Skalski został aresztowany i był więziony aż do 1932 r., kiedy umożliwiono mu wyjazd do Polski. Ks. Skalski jeszcze przed swym uwięzieniem, wiosną 1926 r., mianował dwóch wikariuszy generalnych mających go zastąpić w wypadku aresztowania. Wytypował

\footnotetext{
${ }^{3}$ K. Naskręcki, dz. cyt., s. 38.

${ }^{4}$ K. Kaczkowski, Sprawozdanie złożone Stowarzyszeniu Xięgarsko - Wydawniczemu w Żytomierzu dnia 23 kwietnia 1859 roku, Kijów 1859, s. 22.

${ }^{5}$ K. Naskręcki, dz. cyt., s. 40.

${ }^{6}$ Tamże, s. 61.

7 Tamże.

8 Tamże, s. 62.

9 Tamże.

10 T. Skalski, Terror i cierpienie. Kościół katolicki na Ukrainie 1900-1932. Wspomnienia, oprac. J. Wołczański, Kraków 2008, s. 12-13.
} 
dwóch księży: Kazimierza Naskręckiego i Stanisława Jachniewicza ${ }^{11}$. Pierwszy z wymienionych duchownych pełnił swą funkcję do 26 lipca 1929 r., tj. do dnia aresztowania, zaś drugi do 29 lipca 1935 r., kiedy to również został zatrzymany przez radzieckie organy bezpieczeństwa.

Poza wymienionymi administratorami, w mieście do połowy lat 30 . XX w. pracowało jeszcze kilku innych kapłanów. Szczególnie tragiczna historia wiąże się z postacią ks. Andrzeja Fedorowicza. Zatrzymany i poddany okrutnemu śledztwu od maja do listopada $1924 \mathrm{r}$. zdecydował się ostatecznie na podpisanie fałszywego listu do papieża Piusa XI, iż w ZSRR nie było żadnych prześladowań wierzących wyznania katolickiego, a duchowni tego wyznania trafiający do więzień byli w istocie agentami Polski i prowadzili wywrotową działalność przeciwko państwu radzieckiemu. Ksiądz po podpisaniu tego listu wyszedł na wolność, ale rychło, tj. 4 marca 1925 r., dokonał samospalenia nad rzeką Teterew na obrzeżach Żytomierza.

Po aresztowaniach przez Sowietów poszczególnych kapłanów Kościół katolicki od połowy lat 30. XX w. trwał w mieście przede wszystkim za sprawą sióstr zakonnych serafinek. Jednak i one musiały realizować swą misję nielegalnie, w zasadzie w podziemiu, gdyż wszelkie próby podjęcia oficjalnej działalności religijnej natychmiast zakończyłyby się ich aresztowaniem ${ }^{12}$.

Kościół katolicki w bardzo ograniczonej formie trwał również w pobliżu Żytomierza - w parafiach Kotelnia i Leszczyny, znajdujących się w dekanacie żytomierskim. Natomiast w Nowogradzie Wołyńskim (Zwiahelu) pracował ks. Paweł Welik. Aresztowany został w 1935 r. wespół z 10 innymi osobami z jego parafii. Został skazany na pięć lat łagrów, do Żytomierza powrócił w lutym 1940 r., gdzie przebywał nielegalnie - bez zgody władz. Schronienie znalazł u wspomnianych sióstr serafinek, ale na skutek donosu aresztowany został po raz kolejny. Skazano go na karę śmierci, ale ostatecznie otrzymał wyrok 10 lat łagru, w którym zmarł w 1942 r. $^{13}$

Sytuacja Polaków wyznania rzymsko-katolickiego na terenie Żytomierza i tamtejszej diecezji zmieniła się poważnie z chwilą wybuchu wojny niemiecko-radzieckiej. Pojawiła się wówczas szansa na odbudowę struktur Kościoła w oparciu o duchowieństwo diecezji łuckiej, znajdującej się po 1939 r. pod okupacją niemiecką. Początkowo księża z diecezji łuckiej zaczęli tymczasowo nawiedzać diecezję żytomierską, ale nie podejmowali jeszcze odbudowy tamtejszej sieci parafialnej funkcjonującej do wybuchu wojny. W ramach tej akcji w listopadzie 1941 r. do Olewska przybył jezuita Bogumił Horczak; w grudniu tego samego

${ }^{11}$ Reaktywowanie duszpasterstwa $w$ diecezjach żytomierskiej i kamienieckiej. Materiały źródtowe Kurii Diecezjalnej w Łucku 1941-1945, wyd. M. Dębowska, Rzeszów 2010, s. 7.

${ }^{12}$ K. Naskręcki, dz. cyt., s. 171.

${ }_{13}$ R. Dzwonkowski, Leksykon duchowieństwa polskiego represjonowanego w ZSRS 1939-1988, Lublin 2003, s. 627-628. 
roku do Emilczyna przyjechali księża Ludwik Wrodarczyk i Bolesław Ekiert, a do Trojanowa ksiądz Stanisław Dobrzański i prawdopodobnie ksiądz Piotr Sąsiadek. W marcu 1942 r. ojciec Horczak udał się do Chabnego, a w maju ks. Henryk Dyakowski do Zwiahla. W czerwcu tego samego roku ksiądz Antoni Chomicki przybył do Emilczyna, Krywotenia i Okop. Do tej ostatniej miejscowości pod koniec czerwca i w lipcu przyjechał jeszcze ks. Jan Lewicki. Kilka miesięcy później, w październiku, ks. Lewicki udał się do Rokitnego. W grudniu kapucyn Alojzy Serafin Kaszuba przybył do Horadnicy i Karpiłówki, a ks. Franciszek Oleń do Żytomierza i Horaszek. Wreszcie na święta Bożego Narodzenia 1942 r. do Zwiahla na dłużej przyjechał ks. Dyakowski ${ }^{14}$.

Czasowe wyjazdy księży katolickich do poszczególnych parafii diecezji żytomierskiej stanowiły tylko wstęp do odbudowy struktury Kościoła na tym terenie. Do tego zaś potrzebne było wysłanie na stałe księży do poszczególnych miejscowości, z czym jednak nie było łatwo ze względu na ograniczone możliwości diecezji łuckiej położonej najbliżej Żytomierza. Z kolei próby wysłania kapłanów z terenów bardziej oddalonych wiązały się z tym, iż duchownym trudno było odnaleźć się w skomplikowanych relacjach językowych, narodowych i religijnych panujących na tym terenie. Tym niemniej działania ukierunkowane na odbudowę struktur Kościoła katolickiego w Żytomierzu i jego rejonie zostały podjęte i to już jesienią $1941 \mathrm{r}$. W liście z 1 listopada $1941 \mathrm{r}$., adresowanym do biskupa łuckiego Adolfa Piotra Szelążka (odpowiadającego za projekt odbudowy struktur kościelnych w rejonie Żytomierza), pisze o tym ks. Zygmunt Chmielnicki, zaznaczając jednak, iż potrzeba jeszcze, co najmniej 15 kapłanów do obsadzenia ważniejszych ośrodków.

W pierwszej kolejności kapłana doczekał się oczywiście Żytomierz. Do kościoła katedralnego przybył bowiem ks. Dobrzyński. Do kościoła seminaryjnego w Żytomierzu w listopadzie wysłano ks. Dyakowskiego. Wiosną 1944 r. do Żytomierza przyjechał natomiast ks. Stanisław Szczypta, który objął kościół seminaryjny ${ }^{15}$.

Jednakże akcja obsadzania duchownymi poszczególnych parafii posuwała się niezwykle wolno i opornie. $\mathrm{Z}$ jednej strony nie były zadowolone $\mathrm{z}$ tego faktu okupacyjne władze niemieckie, niejednokrotnie wprost blokując tego typu działania, zaś z drugiej istniał poważny deficyt odpowiednio przygotowanych duchownych. Przybyły w listopadzie 1941 r. do Żytomierza ks. Dyakowski zmuszony był objąć dodatkowo Berdyczów i Korostyszew. Dopiero w marcu 1942 r. do Zasławia wysłano ks. Józefa Kuczuńskiego. Przybyły w maju 1943 r. do Żytomierza ks. Oleń objął, poza tutejszym kościołem katedralnym (przypuszczalnie po ks. Dobrzańskim), administrację (od lipca) wspólnoty w: Goraszkach, Nowym Zawodzie i Kotolni. Parafią w Żytomierzu ks. Oleń będzie kierował niedługo

14 Reaktywowanie duszpasterstwa..., s. 15-30.

15 Ю. Білоусов, Київсько-Житомирська римо-католицька єпархія. Історичний нарис, Житомир 2000, s. 272-273; R. Dzwonkowski, dz. cyt., s. 559. 
- już październiku na stanowisku proboszcza widzimy bowiem ks. Faustyna Lisieckiego $^{16}$.

W czerwcu 1943 r. do Zwiahla przybył ks. Walerian Głowacz, który pokieruje jeszcze parafiami w następujących miejscowościach: Czarnecka, Słobódka, Czarny Bór, Jachłonne, Rychalsk i Kamienny Bród ${ }^{17}$. Bodaj ostatnia grupa duchownych na tereny diecezji żytomierskiej dotarła w październiku 1944 r. Wśród tychże był m.in. ojciec Wojciech Darzycki. Rezydując w parafii Krymek zajmował się jeszcze kilkunastoma innymi parafiami na terenie diecezji żytomierskiej ${ }^{18}$.

W 1944 r. bp Szelążek postanowił wyznaczyć dla diecezji żytomierskiej osobnego ordynariusza. Został nim ks. Bronisław Drzepecki. Jednak zasadniczo zmieniła się w tym czasie sytuacja wojskowo-polityczna na obszarze omawianej diecezji. Mianowicie powróciła władza radziecka. Rządząca partia komunistyczna absolutnie nie zamierzała tolerować odbudowujących się struktur kościelnych. Stosowne przygotowania do przeciwdziałania temu procesowi rozpoczęto już w drugiej połowie 1944 r., a z początkiem 1945 r. przystąpiono do uderzenia. Rozpoczęto od rewizji u samego biskupa łuckiego w nocy z 3 na 4 stycznia, przeprowadzonej przez NKGB. W trakcie przeszukania odnaleziono pismo, które bp Szelążek zamierzał wysłać do Rzymu w sprawie ks. Drzepeckiego. W związku z tym 10 stycznia 1945 r. ks. Drzepecki został aresztowany ${ }^{19}$.

Niedługo potem - 23 stycznia 1945 r. - aresztowanego ks. Szczyptę ${ }^{20}$, a 25 lutego 1945 r. ks. Lisieckiego, który próbował po zatrzymaniu ks. Drzepeckiego pokierować Kościołem na terenie diecezji żytomierskiej ${ }^{21}$. W 1946 r. - 3 marca - aresztowano ojca Darzyckiego ${ }^{22}$.

Aresztowania wielu kapłanów na terenie diecezji żytomierskiej w 1945 i 1946 r. nie oznaczały, iż zupełnie zamarło tam życie religijne. W Żytomierzu po zakończeniu II wojny światowej w dalszym ciągu funkcjonował kościół katedralny, którego z ogromną odwagą i poświęceniem chroniła miejscowa ludność. Nabożeństwa odprawiał w nim ks. Roman Jankowski, który w 1945 r. po 11 latach łagrów opuścił miejsce zesłania i przyjechał właśnie do Żytomierza ${ }^{23}$. Duchowny wkrótce musiał jednak wyjechać z miasta na pięć lat i udać się do nieodległej wsi Jabłonne. Po tym okresie powrócił do Żytomierza i dalej pracował jako duszpasterz przy kościele katedralnym. W czasie jego posługi kapłańskiej, w 1959 r. dokonano chóralnego odnowienia przyrzeczeń chrzcielnych przez wiernych zebranych na nabożeństwie Wielkiej Soboty (zgodnie zresztą z przyjętym rytuałem).

\footnotetext{
16 Reaktywowanie duszpasterstwa..., s. 98 i 102.

17 Tamże, s. 109.

18 R. Dzwonkowski, dz. cyt., s. 190.

19 R. Dzwonkowski, $d z$. cyt., s. 203

20 Tamże, s. 559.

${ }^{21}$ Reaktywowanie duszpasterstwa..., dz. cyt., s. 10-11.

22 R. Dzwonkowski, dz. cyt., s. 190.

23 Tamże, s. 287-288.
} 
Fakt ten został odebrany przez władze jako wymuszona przysięga na wierność Kościołowi. W efekcie ks. Jankowskiemu na pół roku cofnięto stosowne uprawnienia zezwalające na pełnienie obowiązków kapłańskich. W tym samym okresie czasu duchowny odwiedził także Polskę, gdzie spotkał się z prymasem Stefanem Wyszyńskim. Do lat 70. XX w., będąc już w bardzo podeszłym wieku, dojeżdżał jeszcze do miejscowości Zwiahel, Pokostówka i innych. Zmarł w 1987 r. i został pochowany na cmentarzu parafialnym w Żytomierzu ${ }^{24}$.

Księdza Jankowskiego w jego pracy przy kościele katedralnym wspierał ks. Aleksander Samosenko. Dodatkowo opiekował się kaplicą pw. św. Wacława na Kroszni (dzielnica Żytomierza). Jego wielkim sukcesem było uzyskanie zgody władz państwowych na zarejestrowanie odrębnej parafii we wspomnianej dzielnicy Żytomierza. Pracował z wiernymi aż do swojej śmierci w 1956 r. Został pochowany na cmentarzu katolickim w Żytomierzu.

W 1955 r. do miasta powrócił ks. Szczypta. Początkowo staraniem wiernych otrzymał zgodę na pracę w parafii Słobódka pod Żytomierzem. Dopiero po roku pracy w tej parafii mógł przenieść się do samego Żytomierza, gdzie objął stanowisko duszpasterza przy kościele katedralnym ${ }^{25}$.

Działalność księży Jankowskiego, Somosenki i Szczypty wspierał ks. Lisiecki, który w 1956 r. został zwolniony z łagru i powrócił do Żytomierza. Nie uzyskał jednak zgody na pracę duszpasterską i w związku z nielegalnym wykonywaniem posługi kapłańskiej został w 1957 r. aresztowany na pół roku. Wraz z zakończeniem tej kary znów rozpoczął działalność duszpasterską w formie niejawnej, którą kontynuował aż do 1972 r., czyli do śmierci. Jego uroczysty pogrzeb stał się okazją dla wielkiej, jak na ówczesne warunki, manifestacji Polaków wyznania rzymsko-katolickiego ${ }^{26}$.

W 1975 r. do Żytomierza na krótko przybył ks. Józef Świdnicki. Kapłan ten został w 1971 r. potajemnie wyświęcony przez litewskiego biskupa Vincentasa Sladkievičiusa, przebywającego na wygnaniu przy granicy łotewskiej. Ks. Józef Świdnicki po święceniach kapłańskich pracował fizycznie (jako operator dźwigu), co jakiś czas wyjeżdżając na Białoruś i Ukrainę. Wreszcie w 1975 r. dotarł właśnie do Żytomierza, gdzie szybko rozpoczął bardzo intensywną pracę duszpasterską (prawdopodobnie przy tamtejszym kościele katedralnym). Fakt jego zaangażowania szybko nie spodobał się władzom, stąd postawiono przed nim ultimatum - albo podejmie współpracę z organami bezpieczeństwa, albo zmuszony zostanie do opuszczenia Żytomierza. Duchowny nie zdecydował się na przyjęcie tego układu w związku z czym opuścił nie tylko miasto, ale i radziecką Ukrainę. Wyjechał do Kazachstanu, a następnie do Uzbekistanu i Tadżykistanu ${ }^{27}$.

\footnotetext{
${ }^{24}$ Tamże, s. 288.

${ }^{25}$ Ю. Білоусов, $d z$. cyt., s. 272-273.

${ }^{26}$ R. Dzwonkowski, dz. cyt., s. 375.

27 Tamże, s. 586.
} 
Poza Żytomierzem życie religijne Polaków przetrwało po 1945 r. w zaledwie kilku miejscach dawnej diecezji żytomierskiej. Na krótko kapłana w osobie ks. Szczypty uzyskała wspomniana parafia w Słobódce. Ciekawy przykład stanowi natomiast Berdyczów. Świątynia katolicka funkcjonowało tam do 1949 r., kiedy władze zamknęły kościół. W tym stanie rzeczy pełniący tam posługę kapłańską ks. Józef Koziński przeniósł się do odległej o blisko $30 \mathrm{~km}$ od Berdyczowa miejscowości Chałaimgródek, gdzie odprawiał msze. Powrócił do Berdyczowa w 1953 r., gdzie wespół z wiernymi dokonał zakupu niewielkiego domu, od tej pory pełniącego funkcję prowizorycznej świątyni. W tym czasie ks. Koziński dojeżdżał jeszcze do Nowego Zawodu pod Żytomierzem, w którym także celebrował nabożeństwa. Pracował aż do $1967 \mathrm{r}$., tj. do pierwszych lat epoki breżniewowskiej ${ }^{28}$.

Nie ulega wątpliwości, iż poważne zmiany dla Polaków identyfikujących się z polskością i Kościołem katolickim nadeszły w połowie lat 80 . XX w., po odejściu ze stanowiska sekretarza generalnego KC KPZR najpierw Jurija Andropowa, a następnie Konstantina Czernienki. Objęcie kierownictwa w partii w 1985 r. przez stosunkowo młodego i nastawionego proreformatorsko Michaiła Gorbaczowa spowodowało, iż do 1991 r., czyli do rozpadu Związku Radzieckiego, sytuacja Kościoła stale się poprawiała. Znaczne więcej pojawiało się wydawnictw religijnych przywożonych z Polski. Praktyki religijne realizowane przez wierzących nie spotykały się z poważniejszymi ograniczeniami, a wierni rozpoczęli nawet starania o odzyskanie drugiej świątyni katolickiej, tj. kościoła seminaryjnego, co zresztą stało się faktem na początku lat 90 . XX w.

Interesująca sytuacja miała miejsce w Nowogradzie Wołyńskim, inaczej Zwiahlu. Ponieważ w mieście tym od 1935 r. nie było już kościoła i funkcjonowały tylko różne nieformalne kaplice przydomowe, stąd u schyłku lat 80 . XX w. katolicy zwrócili się z prośbą o budowę nowej świątyni. Otrzymali stosowną zgodę i w 1990 r. w mieście stanął - po przeszło 50 latach niebytu - imponujący katolicki kościół.

Uformowanie się i okrzepnięcie struktur Związku Radzieckiego w zasadzie przekreśliło szanse tysięcy Polaków, żyjących w Żytomierzu i jego okolicach, na jakiekolwiek swobody narodowe. Zasadniczym spoiwem ich tożsamości stał się zwalczany administracyjnie i ideologicznie Kościół katolicki. Okresem pewnego wytchnienia był czas okupacji niemieckiej, kiedy zaistniała szansa na częściową odbudowę struktur Kościoła katolickiego. Czas ten jednak dobiegł końca w latach 1945-1946. Ponownie można mówić o odrodzeniu się Kościoła katolickiego dopiero w latach 80. XX w. z chwilą zainicjowania „pierestrojki” przez Michaiła Gorbaczowa. Dzięki zmianom następującym w ZSRR Polakom udało się odzyskać drugą świątynię katolicką w Żytomierzu, ponadto zwracano uwagę na stan techniczny i sprawy własnościowe innych świątyń w pobliżu miasta. Wokół reakty-

${ }^{28}$ Tamże, s. 336 
wujących się parafii odradzała się szeroko rozumiana polskość. Polacy w znacznie większym stopniu niż do tej pory mogli okazywać swoją podmiotowość i odzyskiwali świadomość swojej przeszłości. W tych okolicznościach, z początkiem już lat 90. XX w., z pomocną dłonią starało się przyjść im państwo polskie. Jego władze oraz inicjatywy w stylu Wspólnoty Polskiej oraz sam Kościół katolicki wciąż podejmują liczne starania na rzecz uratowania ostatnich śladów polskości na tym terenie.

Andrzej Kobus

\section{CATHOLIC CHURCH AND RELIGIOUS LIFE OF POLES IN ŻYTOMIERZ BETWEEN 1917-1991}

The presented article is devoted to the religious standing of Poles living in Żytomierz

1 in the Soviet Union times. The author discusses the legal status of Roman Catholic parishes in Żytomierz and its nearest neighbourhood after the Bolshevik Revolution in 1917 and later on. Profiles of Żytomierz Catholic priests have been introducted who acted until the Soviet Union collapse in 1991. Furthermore, the author attempts to show the relations that the Żytomierz Poles held with Poland and her structures of the Roman Catholic Church during the USSR era.

Słowa kluczowe: Kościół Katolicki, represje radzieckie, deportacja

Keywords: Catholic Church, Soviet repression, deportation

\section{BIBLIOGRAFIA}

\section{Źródła publikowane:}

Reaktywowanie duszpasterstwa w diecezjach żytomierskiej i kamienieckiej. Materiały źródłowe Kurii Diecezjalnej w Lucku 1941-1945, wyd. Maria Dębowska, Rzeszów 2010.

\section{Wspomnienia:}

Naskręcki K., Z zapisków i ze wspomnień Żytomierzanina, oprac. Maria Dębowska, Kraków 2011.

Skalski T., Terror i cierpienie. Kościót katolicki na Ukrainie 1900-1932. Wspomnienia, oprac. J. Wołczański, Kraków 2008.

\section{Opracowania:}

Білоусов Ю., Київсько-Житомирська римо-католицька єпархія. Історичний нарис, Житомир 2000.

Dzwonkowski R., Leksykon duchowieństwa polskiego represjonowanego w ZSRS 1939-1988, Lublin 2003.

Kaczkowski K., Sprawozdanie złożone Stowarzyszeniu Xięgarsko - Wydawniczemu w Żytomierzu dnia 23 kwietnia 1859 roku, Kijów 1859.

Кистириця М.Ю., Кондратюк Р.Ю., Житомир, Житомир 2007. 